\title{
$P-677$ 実験的膀胱炎における脖胱璧内サイトカインの検討
}

\section{東北大学}

加藤慎之介、豊田精一、伊藤晋、及川克彦、折笠精一

【目的】膀肬内への細菌の侵入、上皮への付着により感染が成立するとき、速やかな好中球を中心とする 白血球の血管外遊走、浸潤がみられる。この白血球の感染部位への浸潤は、炎症における重要な初期反応 であり、近年、分子レベルでその機構が明らかにされてきている。そこで今回我々は、実験的膀腅炎を作 成し、膀腅壁内での白血球の血管外遊走、浸潤のメカニズムをサイトカイン、特に白血球走化性因子の一 つであるIL-8に着目して検討した。

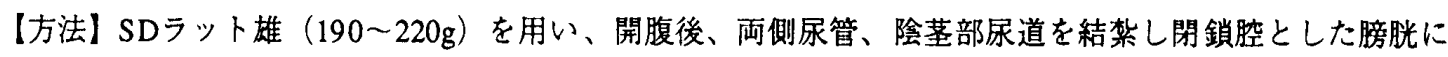
菌体成分Lipopolysaccharide(LPS) $10 \mu \mathrm{g} / \mathrm{ml}$ を注入し、30 分、1、3 時間後に膀胖を摘出した。コントロー ルとして同様にPBSを注入した。摘出した膀胱はPFA固定後、凍結切片を作成し、抗IL-8モノクローナル 抗体を用いて免疫染色を行い、同時にHE染色にて観察した。

【結果および考察】LPS注入後、3 時間でL-8の発現が劲められた。一方、白血球は 30 分後に、少数で はあるが血管外へ遊走して扔り、1 時間、3 時間後では上皮下に多数漫潤していた。LPS刺激後、IL-8発 現以前より白血球は活性化されていることが示唆され、今後、このごく初期の白血球活性化因子、マクロ ファージ及び長時間後の経時的変化について検討を行う予定である。

\section{$P-678$ 梱菌パイオフィルムに対する抗菌寀併用瘦法に関する検討}

岡山大学

小野畫昭, 橋本英昭, 津川昌也, 公文裕巳, 大森弘之

【目的】カテーテル留置複雑性尿路感染症や慢性細菌性前立腺炎をはじめとする難治性細菌感染症の原因と して, 感染病巣局所に形成される細菌バイオフィルムが注目されている。緑膿菌などを起炎菌とする慢性感 染症に抢いては, 細菌細胞は菌体外多糖に覆われ, ほとんどの抗菌燕に对して, 高濃度でも抵抗性を示す。 我々は，細菌バイオフィルムに対する新しい抗菌薬併用療法について検討した。【材料と方法】使用菌株は 尿路性器感染症由来緑澧菌(14-210)及び大腸菌(K108AC,E790,E808,E810), 培地は人工尿を主に用いた。in vitro実験モデルとして modified Robbins deviceを用い，人工尿に終濃度が $10^{6} \mathrm{cfu} / \mathrm{ml}$ となるように接種した菌液 を $37^{\circ} \mathrm{C}, 40 \mathrm{ml} / \mathrm{hr}$ の流速で潅流させ，装着したシリコンディスクにバイオフィルムを形成させた。その後，各 種抗菌薬(GM,PIPC,IPM,OFLX,FOM,CAM,etc.)を含有する人工尿溶液を潅流し，8～72時間作用後の効果を 検討した。同㥞に，抗菌薬投与時の尿中漕度推移をintelligent pumpにて人工尿中にsimulateして検討した。抗 菌勃果の检討は, ATP-bioluminescence法によるbioactivityの変動を指標とし, あわせて走查笔影にて観察して 科佃した。【結果と考察】いずれの菌種においても, 高濃度(50MIC以上)のOFLX以外に, 単剂でbioactivity に直接効果を示すをのはなかった。そこで，OFLXと他剤との併用療法について検討を加えたが，OFLXと FOMの併用では，それぞれ単独では直接影響しない濃度において，相乗効果が認められた。菌液海流8hrの 緑膿菌バイオフィルムでは，OFLX 3MICとFOM1/8MICの併用により，72hr後にbioactivityは約4\%に低下し ていた。また，菌液潅流3hrの緑膿菌バイオフィルムではより高い感受性を示し，除菌効果が得られた。大腸 菌バイオフィルムに扔ても同様の相乗効果を認めた。以上より, OFLXとFOMの併用療法は, 尿路バイオ フィルム感染症に対して，有効な治療法になり得ると考えられた。 